\title{
The Complexity of Food Systems: Defining Relevant Attributes and Indicators for the Evaluation of Food Supply Chains in Spain
}

\author{
Gonzalo Gamboa ${ }^{1, *}$, Zora Kovacic ${ }^{2}$, Marina Di Masso ${ }^{3,4}$, Sara Mingorría ${ }^{2}$, Tiziano Gomiero ${ }^{2}$, \\ Marta Rivera-Ferré ${ }^{4}$ and Mario Giampietro ${ }^{2,5}$ \\ 1 Departament d'Economia i d'Història Economica, Facultat d'Economia i Empresa, \\ Universitat Autònoma de Barcelona, Office B3-112, Building B, Campus UAB, Bellaterra 08193, Spain \\ 2 Institut de Ciència i Tecnologia Ambientals (ICTA), Universitat Autònoma de Barcelona, Campus UAB, \\ Bellaterra 08193, Spain; zora.kovacic@uab.cat (Z.K.); sara.mingorria@gmail.com (S.M.); \\ tiziano.gomiero@libero.it (T.G.); mario.giampietro@uab.cat (M.G.) \\ 3 Internet Interdisciplinary Institute (IN3), Universitat Oberta de Catalunya (UOC), \\ Av. Carl Friedrich Gauss, 5, Castelldefels 08060, Spain; madimasso@gmail.com \\ 4 Facultat de Ciències i Tecnologia, Universitat de Vic - Universitat Central de Catalunya, Barcelona 08500, \\ Spain; martaguadalupe.rivera@uvic.cat \\ 5 Institució Catalana de Recerca i Estudis Avançats (ICREA), Passeig Lluís Companys, 23, \\ Barcelona 08010, Spain \\ * Correspondence: gonzalo.gamboa@uab.cat or gonzalo@moviments.net; Tel.: +34-93-581-41-04; \\ Fax: +34-93-581-20-12
}

Academic Editor: Gianluca Brunori

Received: 15 January 2016; Accepted: 19 May 2016; Published: 27 May 2016

\begin{abstract}
The wide-ranging literature on food systems provides multiple perspectives and world views. Various stakeholders define food and food systems in non-equivalent ways. The perception of the performance of food systems is determined by these specific perspectives, and a wide variety of policies responding to different aims are proposed and implemented accordingly. This paper sets out to demonstrate that the pre-analytical adoption of different narratives about the food system leads to non-equivalent assessments of the performance of food supply chains. In order to do so, we (i) identify a set of relevant narratives on food supply chains in Spanish and Catalan contexts; (ii) identify the pertinent attributes needed to describe and represent food supply chains within the different perspectives or narratives; and (iii) carry out an integrated assessment of three organic tomato supply chains from the different perspectives. In doing so, the paper proposes an analysis of narratives to enable the analyst to characterize the performance of food supply chains from different perspectives and to identify the expected trade-offs of integrated assessment, associating them with the legitimate-but-contrasting views found among the social actors involved.
\end{abstract}

Keywords: food systems; food supply chains; narratives; integrated assessment

\section{Introduction}

Food systems concern the way food is produced, transformed, made available to people, and consumed by them [1-3]. The wide-ranging literature on food systems provides multiple perspectives and world views [2-5]. This plurality can be observed in (i) the many non-equivalent definitions of food and food systems; (ii) the wide variety of policies responding to different aims associated with food quality, quantity, sustainability, productivity, profitability, etc.; and (iii) the multiplicity of stakeholders involved in the production, distribution, and consumption of food and in the management of food systems. 
As a useful conceptualization, a food system can be defined as a chain of activities, ranging from production in the field to consumption, with particular emphasis on processing, marketing, and the multiple transformations of food that these activities entail [2,5]. The food system links three different aspects of life: (1) biological, i.e., the living processes used to produce food and their ecological sustainability; (2) economic and political, i.e., the power and control which different groups exert over the different parts of the system; and (3) social, i.e., the personal relations, community values, and cultural traditions which affect people's use of food [1].

At present, the sustainability of food systems faces many challenges. It has been argued that the environmental impact of agricultural activities (e.g., pollution, soil degradation, water use, biodiversity loss) may threaten our ability to cope with the challenges posed by climatic extremes, the future of food security, and human health [6-12].

Notwithstanding the achievements of the green revolution and the industrialization of agriculture, approximately 900 million people are undernourished worldwide and malnutrition affects 2 billion people [13]. In contrast, nearly 2 billion people are overweight, 600 million of whom are obese [14], which has led scholars to talk about the "global obesity epidemic" [14-16]. Also, food system waste is a massive issue, possibly accounting for $30 \%-40 \%$ of total agricultural production, and concerns developing and developed countries alike [17-19]. High productivity has not helped farmers to attain the wages enjoyed by other productive sectors: they have been trapped by debts and were in thrall to powerful agribusiness corporations $[2,20,21]$. Different food systems are associated with different challenges, and different stakeholders may hold different views about what a food system is and how it must be organized to face these challenges.

Food has both a material and symbolic power that involves complex links between nature, human survival, health, culture, and livelihood $[2,21,22]$. In Europe, as in the USA, some tangible signs of the importance of all its dimensions are evident: for example, in the steadily increasing demand for organic products [23-25], the rediscovery of local and traditional productions (e.g., the success of the Slow Food movement), the increasing number of people participating in ethical purchasing groups, and the spread of local food/farmers markets [2,26-28]. As Hinrichs [26] (p. 33) points out "'Local food' has emerged as a banner under which people attempt to counteract trends of economic concentration, social disempowerment, and environmental degradation in the food and agricultural landscape, but it may differ from a bio-politics centred more explicitly on either organic or sustainable agriculture and food."

The concern about food quality and food safety is high and widespread among European consumers, as is the demand for information about the origins of the food products and their composition. It seems, as well, that consumers tend to associate locally produced food with better quality or lower environmental impact. A different sort of concern is also spreading among many stakeholders (e.g., farmers, consumers, citizens) related to increasing concentrations of power in the food system that may lead to a food monopoly [2,21,29-31]. It has also been highlighted that the food system is becoming a battlefield, upon which powerful economic forces (i.e., agribusiness corporations, traders, processors, financial speculators) try to take control and impose their interests on weaker social actors such as producers and consumers [2,20,21,29,30,32].

Over the last few years, such issues have been analyzed by both the European Commission (EC) (e.g., [33,34]) and other international institutions such as the Food and Agriculture Organization (FAO) $[2,21,35]$. Faced with the ever-increasing public demand for a more sustainable food system and safer products, the EC is addressing the issue by working out possible ways of assessing the performance of the various parts of food supply chains, in order to develop European-wide food policies. All of the different aspects of food supply chains need to be considered in their assessment.

Owing to the many domains involved and the different scales on which different processes take place (from households to the global market), food systems are inherently highly complex systems: That is, their relevant aspects cannot be captured from a single perspective, and therefore different stakeholders may have different perceptions of what a food system is and how it performs. In order, 
then, to properly grasp the functioning and complexity of the food system, a multiplicity of dimensions must be addressed [2,21,30,36,37].

Multiple food supply chains (of different products) make up a food system. Food supply chains have been generally categorized as "local" and "global." Although closeness (the physical-geographical distance to the production place) is usually considered the correct measure to assess local productions, the distinction between local and global food systems is not so clear $[38,39]$. For instance, since the food system is currently highly globalized and complex [1,2,17,21,30,31,36,37], fuels, energy, agrochemicals, machinery, seeds, workforce, credit, subsidies, markets, and knowledge are the global resources of any local production.

This paper sets out to demonstrate that the pre-analytical adoption of different narratives on the food system leads to non-equivalent assessments of the performance of food supply chains. In order to do so, we (i) identify a set of relevant and plausible narratives about food supply chains found in Spanish and Catalan contexts (Quality check on issue definition); (ii) identify the pertinent attributes needed to describe and represent food supply chains within the different narratives (Quality check on integrated analysis). Pertinent "attributes" are observable qualities used to characterize a system, which allow us to describe and evaluate its behavior and characteristics; and (iii) carry out an integrated assessment of three organic tomato supply chains from different perspectives (i.e., adopting different coupling of narratives and attributes).

\section{Theoretical Approach for the Appraisal and Assessment of Global and Local Food Chains}

Over the last few decades, the use of scientific information in policies has increased in the face of complex issues such as climate change, genetically modified organisms, peak oil, and water and mineral scarcity, many of which are linked to food systems [40]. Being confronted with high levels of uncertainty means that science cannot be expected to provide the absolute truth, or answers and solutions to all problems. To face situations of high uncertainty and stakes, Funtowicz and Ravetz [41] have developed the concept of "post-normal science" as an alternative model of science policy. They call for an extended community of interested stakeholders, including scientists from different disciplines, policy makers, and citizens, to assess the quality of the scientific information used for policy making.

In this context of uncertainty, the concept of quality acquires a new meaning. Quality, in relation to science and policy, has internal and external components [42]. Internal quality is concerned with the different levels of skills required for scientific practice and has to be assessed according to the criteria defined within the field of practice. External quality has to do with the wider context in which a knowledge claim is made; it is defined according to a broader community of users (i.e., society) and is related to fitness for purpose and societal relevance.

This is the case of food-related policies, such as food security, which refers to the ability of a region or country to secure access to food for its population. Different actors may perceive and represent the food system in different ways, depending on their different backgrounds, and propose different and contrasting policies to deal with food security at different levels $[1,2,21,30,31,36,43]$. Figure 1 illustrates how different people with different backgrounds propose different lines of action for confronting the problem of food security. This complexity cannot be captured using only one perspective and one scale of analysis: Its appraisal requires the integration of different, sometimes contrasting, points of view (see [36], for an exhaustive treatment of the issue).

The production of scientific information about a complex food system entails a compression of the wide range of possible observables into a limited set of characteristics of a given state of affairs that have been analyzed at a specific point in time according to a pre-analytical choice of narrative [36,44]. First, the complex issue is interpreted through a set of narratives, expectations, and goals that delimit the problem at hand (i.e., issue definition). Secondly, a description is created through the formal definition of a limited set of attributes and indicators. 
Checking the quality (usefulness) of the chosen issue definition for sustainability

International Conference on World Food Security SAGUF - Zurich, October 9-10, 1996

\begin{tabular}{ll}
\hline $\begin{array}{l}\text { National Policy } \\
\text { Keep prices of food commodities LOW } \\
\text { Keep prices of food commodities HIGH }\end{array}$ & $\begin{array}{l}\text { I.F.P.R.I. - U.S. Scientist } \\
\text { Ag. Econ. - Prof. from Pakistan }\end{array}$ \\
\hline $\begin{array}{l}\text { International Policy } \\
\text { REDUCING imports from the SOUTH }\end{array}$ & Wuppertal Inst. - German scientist \\
INCREASING imports from the SOUTH & Ag. Dev. - Prof. from Ghana \\
\hline $\begin{array}{l}\text { SOcial Policy } \\
\text { PRESERVING local cultural heritage } \\
\text { FIGHTING local cultural heritage }\end{array}$ & NGO - Swiss feminist \\
\hline
\end{tabular}

Figure 1. Example of different discourses that define the problem and propose a solution: the plurality of policy proposals to meet food security (source: own elaboration from [36]).

In this process, any formalized description of the problem using a finite set of attributes, indicators, data, and models unavoidably generates hypo-cognition, i.e., the risk of the tunnel-vision effect generated by the adoption of a given frame of analysis [45]. Hypo-cognition may hamper the capacity to deal with the implications of uncertainty and complexity due to the choice to ignore relevant known knowns (i.e., alternative problem framings), the risk of missing relevant known unknowns (i.e., dealing with uncertainty) and a poor handling of unknown unknowns (i.e., dealing with ignorance). As a consequence, without a quality check of the choice of narrative, more data and larger models developed using the same explanations and perceptions will only increase the level of ignorance and uncertainty, leaving untouched the problem framing and its associated level of hypo-cognition [46]. Food system assessments and policy design take place in this scenario [47].

The adoption of a given issue definition and problem structuring means that information not pertaining to the model or measurement scheme used is left aside. Often, this information has to be ignored for the model to remain operational: In this case, we deal with a phenomenon of "socially constructed ignorance" [48]. The usefulness of the model is based on the assessment of how important and relevant the information left aside is [49]. To assess this, an external quality check is required, which entails the participation and collaboration of all relevant social actors, and which avoids a purely technical perspective [50].

In order to better tackle such an issue, this paper checks the usefulness and the pertinence [51] of the pre-analytical choice of narratives behind a given issue definition (semantic framing) and problem structuring (formal framing). More specifically, when dealing with quantitative information used for governance, the double check proposed makes it possible to assess the quality of the narratives chosen to support a given policy or technical innovation. Narratives can be defined as stories that identify the relations of causality used to structure one's perception of the observed system and to define what is relevant among the infinitely rich dynamics that can be considered when dealing with complex policy issues [52,53]. Narratives are chosen in the pre-analytical phase, before crunching numbers. Therefore, the choice of narrative precedes the choice of discipline and of indicators to be used in the formal framing. For example, the endorsement of the economic narrative leads to a formal representation of food systems based on productivity, prices, and supply and demand.

The assessment of the relevance and quality of the choice of narrative cannot be undertaken using formal models or by adopting the wisdom of disciplinary knowledge (economics, ecology, sociology). 
Disciplinary knowledge assumes by default that the narrative within which the analysis is carried out is relevant, pertinent, and useful for dealing with the proposed issue [46].

The analysis of narratives is by nature interdisciplinary because it has to address and answer a set of questions, in the pre-analytical phase, determining which scientific disciplines should be considered when dealing with a specific issue: What are the relevant features of the performance of the system? How can these factors be observed and studied? What is the expected set of relations that will be associated with the concept of performance? When dealing with complex issues, an integrated check of the robustness of the chosen narrative can be carried out only after having discussed the implications of the pre-analytical issue definition and the resulting problem structuring with those who have to use the results of the analysis.

The analysis of narratives and the subsequent definition of attributes and indicators aim to represent a radical change in the deployment of quantitative information for governance. It abandons the Cartesian dream of prediction and control that seeks to use models and quantitative indicators to identify the best course of action (optimizing or minimizing functions), assuming that the information used in the process of deliberation (pre-analytical choice of narrative, choice of models and data) is reliable "by default." By contrast, quantitative analysis is used to improve the robustness of the information used in the process of deliberation: Quantitative information is used to falsify the narratives that are assumed to be valid when defining policies. The focus on narratives rather than on indicators avoids the trap of "solving" the complexity associated with the interaction with the external world by simplification (i.e., the use of quantitative models based on the choice of one narrative, one scale, and one dimension at the time) and proposes the simultaneous use of different assessments that refer to different scales and dimensions of analysis, considering the unavoidable existence of legitimate and non-equivalent perceptions of performance among different relevant actors.

Our analysis focuses on how we can assess the performance of a food chain, in relation to different dimensions (ecological, social, economic, technical) and different scales (the farm, the whole chain at national level), by combining a set of multidimensional attributes and indicators defined from non-equivalent narratives. In this way it becomes possible to identify the expected trade-offs of integrated assessment and associate them with the legitimate-but-contrasting views of the social actors involved. In addition, the quality of the narratives chosen to support a given policy is assessed by contrasting the results of the evaluation (i.e., indicators scores) with what is expected (and expressed) by the narrative.

\section{Methods and Materials}

The food supply chain has been chosen as the analytical framework for considering the local and global aspects of food provisioning, from production to consumption. The analysis is developed in three steps: (1) the identification of narratives about food supply chains; (2) the selection of the attributes in relation to the narratives defined; and (3) the translation of the attributes to indicators.

Successively, three food supply chains are evaluated and compared using a set of multidimensional indicators. Indicators are operational representations of attributes, defined in terms of a specific measurement or observation procedure. The value of the indicator provides information about the condition and/or trend of an attribute of the system considered. The remainder of this section presents in more detail the theoretical and methodological aspects of this process.

\subsection{Scoping and Framing the Analysis of Food Supply Chains: Narratives, Attributes, and Indicators}

The first step is the identification of the narratives used to define the relevant issues to be analyzed. Narratives are analytical tools used to identify the claims of the story-teller (here defined as an actor who chooses a given narrative to organize the information about the perceptions of external events in order to support action). 
The narratives on food supply chains in Catalonia and Spain were identified by analyzing different types of documents. Textual analysis represents a relatively simple, cost-effective approach, which permits the identification of those attributes that characterize the narratives of different typologies of stakeholders. Characterization of the narratives is a key step in assessing the performance of different food supply chains from different perspectives and analyzing trade-offs. Such a methodology can provide technicians and policy makers with a first round of information that can help to better frame the issues at stake, and in turn can assist in the process of policy making-a process in which stakeholders can be directly involved.

The textual analysis was carried out using two different methods and software: content analysis with Atlas.ti and lexicometric (statistical) analysis with Iramuteq. Content analysis aimed to identify attributes used to describe and represent food supply chains in articles, technical reports and legislation, and lexicometric analysis was used to identify narratives used in newspaper articles in order to complement the outcomes of the content analysis.

\subsubsection{Content Analysis}

The first step of the textual analysis involved identifying the sources of information. We collected potential sources of information, including newspapers, magazines, scientific journals, websites, blogs, and TV programs. A total of 86 references were collected that covered different spheres. The term "sphere" refers to communication spaces formed by actors, means, and discourses; the term is used to delimit different communication practices. Within the GLAMUR project (the work presented here was part of the GLAMUR project). The aim of GLAMUR was to increase the knowledge about the performance of food supply chains in order to advance their sustainability by means of public and private policies. Partners of the project have evaluated and compared several food supply chains from economic, social, environmental, health, and ethical perspectives, and reflected on methodological aspects that emerge when assessing and comparing food supply chains. A multiple case-study design was applied, which involved supply chains of products. Products were chosen from five categories: pork, dairy, fruit and vegetables, wine, and grains. The local and global supply chains of each selected product were evaluated in two different countries in order to obtain as much diversity as possible. In the case of Catalonia, Spain, where organic tomato and apple supply chains were analyzed, four spheres were identified: the market, and the public, policy, and scientific spheres. The market sphere refers to the space in which consumers choose and buy commodities. The public sphere is where citizens debate common issues and alternative discourses may emerge [54]. The policy sphere is the place in which different social actors (policy makers, organized and non-organized citizens, and private companies among others) communicate and discuss public policies. The scientific sphere is where scientific knowledge is produced and discussed.

A web search was conducted (in Spanish, Catalan and English) using the search engine Google on key websites, such as those of public ministries and statistical bureaus, to find suitable references published in the last five years from the public, scientific, market, and policy spheres (Table 1). The documents were ordered from the most recent to the oldest and were read in order to ascertain that the topics of interest were properly dealt with and to avoid including documents with an overly generic review of the issues. The documents that related best to the scope of the analysis were selected.

The list of references is divided as follows: 17 from the public sphere, 18 from the market sphere, 17 from the policy sphere and 34 from the scientific sphere. All documents were reviewed, and those dealing with food supply chains in Catalonia and Spain were selected for an in-depth content analysis, resulting in a total of 11 (Table 2).

The documents were qualitatively analyzed using Atlas.ti software. The software makes it possible to code paragraphs (i.e., quotes) and structure the textual analysis according to the codes and sources of information. In this case, the codes referred to the observable qualities (i.e., attributes) used by the author(s) of the text for the characterization of food chains. Quotations were then exported and structured in a table containing the following information: 
a The quotes and corresponding codes,

b The related codes (some quotes are coded with more than one code),

c The source document,

d The sphere to which the documents belongs to, and

e The narrative endorsed by the quote, referring to the content of the article.

Using this structure, a narrative was assigned to each quote based on a set of narratives pre-defined by the research team. The pre-defined narratives were defined as tentative categories based on the experience of the research team. The Commodity narrative views food as a commodity, and the food supply chains are mainly described and evaluated in economic terms. The Food security narrative focuses on people's access to food, with regards to both quantity and quality; the Livelihood narrative has a complex view of food, which is related to identity and culture, rural development issues, and working conditions; and the Environmental narrative prioritizes the ecological aspects related to food supply chains, focusing on climate change impact, animal welfare, and ecosystems.

These narratives were defined in very general terms, leaving room for further refinement during and after the textual analysis. This approach also allows for new narratives, encompassing aspects relevant for the description and representation of the food supply chain that were not considered in the predefined narratives, to emerge from the analysis.

Table 1. Websites, keywords, and language of keywords used to search relevant literature for textual analysis.

\begin{tabular}{|c|c|c|c|c|}
\hline Sphere & $\begin{array}{c}\text { Websites Used for } \\
\text { the Search }\end{array}$ & $\begin{array}{l}\text { Language of } \\
\text { Keywords }\end{array}$ & \multicolumn{2}{|c|}{ Keywords } \\
\hline Public & $\begin{array}{l}\text { Google and the websites of } \\
\text { companies, distribution } \\
\text { chains, cooperatives, public } \\
\text { institutions, NGOs }\end{array}$ & $\begin{array}{l}\text { Spanish } \\
\text { Catalan }\end{array}$ & $\begin{array}{ll}\text { - } & \text { cultural aspect of food } \\
\text { - } & \text { food affordability } \\
\text { - } & \text { food price } \\
\text { - } & \text { food policy } \\
\text { - } & \text { food security } \\
\text { - } & \text { food safety } \\
\text { - } & \text { local food }\end{array}$ & $\begin{array}{ll}\text { - } & \text { long/global food chain } \\
\text { - } & \text { local/global market } \\
\text { - } & \text { purchasing groups } \\
\text { - } & \text { organic food } \\
\text { - } & \text { short food chain } \\
\text { - } & \text { traditional food } \\
& \text { and cuisine }\end{array}$ \\
\hline Scientific & $\begin{array}{l}\text { Google, Google scholar and } \\
\text { the websites of public } \\
\text { institutions, agricultural } \\
\text { associations, environmental } \\
\text { associations, NGOs }\end{array}$ & $\begin{array}{l}\text { Spanish } \\
\text { Catalan } \\
\text { English }\end{array}$ & $\begin{array}{ll}\text { - } & \text { farming system assessment } \\
\text { - } & \text { food chain } \\
\text { - } & \text { food policy } \\
\text { - } & \text { food quality } \\
\text { - } & \text { food sovereignty } \\
\text { - } & \text { food system } \\
\text { - } & \text { food system assessment }\end{array}$ & $\begin{array}{ll}\text { - } & \text { food system analysis } \\
\text { - } & \text { local food production, } \\
\text { - } & \text { local food market } \\
\text { - } & \text { organic agriculture } \\
\text { - } & \text { participatory approach } \\
\text { - } & \text { short food chain }\end{array}$ \\
\hline Market & $\begin{array}{l}\text { Google and the websites of } \\
\text { companies, distribution } \\
\text { chains, production } \\
\text { cooperatives and } \\
\text { public institutions }\end{array}$ & $\begin{array}{l}\text { Spanish } \\
\text { Catalan } \\
\text { English }\end{array}$ & $\begin{array}{ll}\text { - } & \text { direct sales } \\
\text { - } & \text { distribution chain } \\
\text { - } & \text { food affordability } \\
\text { - } & \text { food price } \\
\text { - } & \text { food quality } \\
\text { - } & \text { food safety } \\
\text { - } & \text { local/global food chain }\end{array}$ & $\begin{array}{ll}\text { - } & \text { local/global market } \\
\text { - } & \text { market policy } \\
\text { - } & \text { organic agriculture } \\
\text { - } & \text { production cost } \\
\text { - } & \text { shorchasing groups } \\
& \text { shood chain }\end{array}$ \\
\hline Policy & $\begin{array}{l}\text { Google and the websites of } \\
\text { public institutions } \\
\text { and NGOs }\end{array}$ & $\begin{array}{l}\text { Spanish } \\
\text { Catalan }\end{array}$ & $\begin{array}{ll}\text { - } & \text { access to food } \\
\text { - } & \text { agricultural policy } \\
\text { - } & \text { common agricultural policy } \\
\text { - } & \text { food affordability } \\
\text { - } & \text { food policy } \\
\text { - } & \text { food policy } \\
\text { - } & \text { food price }\end{array}$ & $\begin{array}{ll}\text { - } & \text { food security } \\
\text { - } & \text { food sovereignty } \\
\text { - } & \text { local food } \\
\text { - } & \text { local food chain } \\
\text { - } & \text { local market } \\
\text { - } & \text { organic agriculture } \\
\text { - } & \text { organic food }\end{array}$ \\
\hline
\end{tabular}


Table 2. Reviewed articles by sphere.

\begin{tabular}{|c|c|c|c|c|}
\hline Title of Document & Author(s) & Sphere & $\begin{array}{l}\text { Geographical } \\
\text { Scope }\end{array}$ & Focus \\
\hline $\begin{array}{l}\text { DECREE } 24 / 2013 \text { of } 8 \text { January, on the } \\
\text { accreditation of the sale of local } \\
\text { food products. }\end{array}$ & $\begin{array}{l}\text { Generalitat de Catalunya } \\
\text { (Catalan government) }\end{array}$ & Policy & Catalonia & $\begin{array}{l}\text { Labeling of food } \\
\text { of proximity }\end{array}$ \\
\hline $\begin{array}{l}\text { La distribución agroalimentaria y } \\
\text { transformaciones estratégicas en la } \\
\text { cadena de valor (Agrifood } \\
\text { distribution and strategic } \\
\text { transformations in the value chain) }\end{array}$ & SDV Consulting & Policy & Spain & $\begin{array}{l}\text { Analysis of the challenges of } \\
\text { the value chain in the } \\
\text { agrifood system and } \\
\text { policy recommendations }\end{array}$ \\
\hline $\begin{array}{l}\text { Programa de desarrollo rural de } \\
\text { Cataluña: 2007-2013 (Catalan rural } \\
\text { development program: 2007-2013) }\end{array}$ & Generalitat de Catalunya & Policy & Catalonia & Rural development policies \\
\hline $\begin{array}{l}\text { Compra pública en sistemas } \\
\text { alimentarios locales (Public } \\
\text { procurement in local food systems) }\end{array}$ & $\begin{array}{l}\text { Veterinarians without } \\
\text { border-VSF }\end{array}$ & Public & Spain & $\begin{array}{l}\text { Social, environmental, and } \\
\text { economic impacts of the } \\
\text { food systems and the role of } \\
\text { public procurement }\end{array}$ \\
\hline $\begin{array}{l}\text { La cadena agroalimentaria en España } \\
\text { (The agrifood chain in Spain) }\end{array}$ & $\begin{array}{l}\text { Giménez, J.D., Campos, R., } \\
\text { Gómez-Bengoechea, G. }\end{array}$ & Public & Spain & $\begin{array}{l}\text { Spanish agrifood chain: } \\
\text { added value creation and } \\
\text { distribution, market share, } \\
\text { and regulation obstacles }\end{array}$ \\
\hline $\begin{array}{l}\text { Dossier d'aprenentatge i de garantia } \\
\text { participativa (Dossier of learning and } \\
\text { participatory guaranty) }\end{array}$ & $\begin{array}{l}\text { La Xarxeta. Pagesos } \\
\text { agroecologics de Catalunya } \\
\text { (Network of Catalan } \\
\text { agroecological farmers) }\end{array}$ & Public & Catalonia & $\begin{array}{l}\text { Presentation of the } \\
\text { network and criteria } \\
\text { for the participatory } \\
\text { guaranty system }\end{array}$ \\
\hline $\begin{array}{l}\text { Business strategies, profitability, and } \\
\text { efficiency of production }\end{array}$ & Alarcon, S., Sánchez, M. & Scientific & $\begin{array}{l}\text { Ebro River } \\
\text { basin }\end{array}$ & $\begin{array}{l}\text { Examine outcomes of } \\
\text { organizational strategies in } \\
\text { the food industry }\end{array}$ \\
\hline $\begin{array}{l}\text { 'Sustainable de-growth' in agriculture } \\
\text { and food: an agro-ecological } \\
\text { perspective on Spain's agrifood } \\
\text { system (2000) }\end{array}$ & $\begin{array}{l}\text { Infante-Amate, J., } \\
\text { Gonzalez de Molina, M. }\end{array}$ & Scientific & Spain & $\begin{array}{l}\text { Energy consumption in } \\
\text { Spanish agrifood systems }\end{array}$ \\
\hline $\begin{array}{l}\text { La cadena agroalimentaria española: } \\
\text { ¿hay lugar para una propuesta de } \\
\text { valor? (The Spanish agrifood chain. Is } \\
\text { there a place for a value proposal?) }\end{array}$ & Boccherini, J.A. & Market & Spain & $\begin{array}{l}\text { Competition in the Spanish } \\
\text { agrifood chains, changes in } \\
\text { consumer behavior, and } \\
\text { challenges for companies }\end{array}$ \\
\hline $\begin{array}{l}\text { Innovación y coordinación entre los } \\
\text { agentes de la cadena de valor, claves } \\
\text { en el futuro de la industria } \\
\text { agroalimentaria (Innovation and } \\
\text { coordination among the value chain } \\
\text { agents, key points in the future of the } \\
\text { agrifood industry) }\end{array}$ & $\begin{array}{l}\text { García-Reyero, M., } \\
\text { Puelles, M. }\end{array}$ & Market & Spain & $\begin{array}{l}\text { Business strategies to meet } \\
\text { consumer demands, } \\
\text { focusing on the citrus, wine, } \\
\text { and olive (oil) industries }\end{array}$ \\
\hline $\begin{array}{l}\text { Los intermediarios mayoristas en la } \\
\text { cadena de valor de alimentación } \\
\text { fresca (Wholesale intermediaries in } \\
\text { the value chain of fresh food) }\end{array}$ & Cruz-Roche, I. & Market & Spain & $\begin{array}{l}\text { Strategies and contribution } \\
\text { of Spanish wholesale } \\
\text { intermediaries }\end{array}$ \\
\hline
\end{tabular}

\subsubsection{Lexicometric Analysis}

In addition, 72 newspaper articles were selected from the three major newspapers in Catalonia (La Vanguardia, El País, and El Periódico) and from the online magazine qcom.es specialized in agro-food chains. These articles were subject to lexicometric analysis using Iramuteq software in order to complement the textual analysis with information from the media. Lexicometry is the measurement of the frequency of co-occurrence of words in a text. The software used provides statistical indicators and graphical representations that enable the analysis of written texts. Among the many features of the software-semantic classifications, factor analyses, similarity analyses, word clouds, lexical density, and intertextual measures are some other indicators and representations provided by the analysis; they compress information contained in large texts and provide new perspectives for analyzing texts-we used cluster analysis to study the text. For this analysis, the software divides the body of the text into segments, within which words are counted. Iramuteq uses a dictionary to transform verbal 
tenses into the infinitive form, plural into singular, and makes adjectives masculine in order to count words with similar roots as the same word. It then performs a hierarchical clustering of text segments according to the frequency of the words within the selected segments. The resulting clusters group text segments containing specific words that are used together when articulating a narrative. The resulting clusters are considered the main narratives about food supply chains contained in the 72 analyzed newspaper articles.

The number of clusters is usually defined according to specific statistical tests and/or methods (i.e., similarity index). However, the resulting clusters should be useful for the purpose of the analysis [55], which requires that the number of relevant clusters is based on researcher's experience and knowledge acquired prior and during the analysis.

\subsubsection{Constructing Narratives}

As a result of the textual analysis, a list of quotes containing the main attributes used to describe and represent food supply chains was obtained. These attributes were assigned to different predefined narratives. Based on the attributes, it was possible to identify the different narratives within each document. Generally, even though more than one narrative was adopted in each document, it was possible to identify a dominant narrative for each document, which enabled the research group to build more refined narratives from the different documents expressing that position. Quotes were used to identify and define four relevant narratives contained in the documents analyzed using Atlas.ti.

In parallel, the analysis performed with Iramuteq produced a set of clusters which are considered the main narratives expressed in the selected newspaper articles. In this case, the software provided the characteristic sentences of each cluster, which were used to describe the different narratives about food supply chains.

Narratives constructed by means of the two methods and from different sources were merged in the final identification of narratives about food supply chains. From these narratives, the research team defined the main attributes used to describe and represent food supply chains in each case.

It should be noted that, in the real world, narratives are not clearly defined: Often their limits are fuzzy and overlap with each other. Each document may contain one, or more than one, narrative. In the same way, no actor has a single narrative or adopts a given rationale determined by a single narrative. Instead, stakeholders combine arguments and attributes from different ideal narratives to construct their own discourses. Therefore, certain attributes are not used exclusively in one narrative. Rather, narratives prioritize or endow some attributes with greater importance, describe and represent food supply chains, and neglect others. Therefore, this work uses "pure" narratives as a simplification of narratives found in the real world. Narratives used in this work aim to demonstrate the contradictions between different points of view and the consequences in the results of an evaluation when choosing one or other issue definition to frame the problem.

\subsubsection{From Narratives to Attributes and Indicators}

A set of attributes can be associated with each narrative. Based on the textual analysis, a list of quotes containing the main attributes used to describe food supply chains was obtained. Attributes are the elements used within the specific narrative to describe a system. For example, the assertion that "low employment in rural areas should be the focus of policy" contains a value judgment, which is used to identify "rural employment" as an attribute within this document. In order to perform a quantitative characterization of the system under study, it is necessary to define the formal categories that map these attributes and allow the analyst to measure and monitor the state of the system according to each attribute. Indicators are thus a means of representing an attribute (description of an observable relevant quality) of the system. An indicator can be defined as the image of an attribute, formalized in terms of a specific measurement. For example, the number of people employed in agriculture can be used as the indicator for the attribute "rural employment." The value of the indicator (i.e., the state of the variable) provides information about the condition and/or the trend of the attribute of the system. 
Currently, there is no methodological framework that is used to define performance indicators from attributes. That is, when defining an indicator in order to measure and represent an attribute, there are no fixed rules or guidelines to support the social analyst in his/her decision about which indicator to use. Indeed, Bouyssou [56] states that the construction of indicators depends more on the art and the experience of the analyst than on the scientific method.

In this paper, we use the accounting framework of the Multi-Scale Integrated Assessment of Societal and Ecosystem Metabolism (MuSIASEM) approach [44] to translate from attributes to a set of performance indicators. The MuSIASEM approach uses the flow-fund model proposed by Georgescu-Roegen [57], which distinguishes between fund elements (what the system is made of) and flows (what the system is processing and exchanging with its context).

Fund and flow categories can be combined in order to characterize the system in quantitative terms. As a result, quantitative indicators can consist of either extensive or intensive variables. Extensive variables translate into indicators expressed in quantities that can be added. They characterize the size of the system and its compartments in terms of either fund categories representing what the system is (e.g., surface of land use, amount of human activity) or flow categories representing what the system does (e.g., amount of production, use of fossil fuels, added value generated).It should be noted that, despite the apparent similarity with the stock-flow model used in mainstream economics, there are fundamental differences which make both models distinct. In the fund-flow model, on the time scale of the representation, fund categories transform inflows into outflows, and flows are either consumed or generated in order to reproduce the funds. Fund categories are those that maintain their identity during the time frame of the representation (e.g., Ricardian land, people, and capital), and flows are those elements that appear or disappear during the time frame of the representation (e.g., added value, energy, residues). In the stock-flow model, flows are obtained and consumed (or produced and supplied) during the same period, and stocks are goods that are held at the end of the current period as an asset. In practical terms, the difference between stocks and flows is that stock variables are measured in absolute terms at a specific point in time, and flows are measured over an interval of time. A flow accumulates in a stock and a stock dissipates in a flow [57]. In the fund-flow model, the stock would be equivalent to what Georgescu-Roegen [58] calls a fund-process: which are "goods in process."

Intensive variables translate into indicators that represent a ratio, a qualitative characteristic, "per unit" of system size. They describe how the system does what it does. These ratios can be constructed using funds or flow categories referring to different levels of analysis or to the same level. In the case of different levels of analysis, intensive indicators are used to characterize the hierarchical relations within the system. For example, the fund $\mathrm{d}_{i-1} /$ fund $_{\mathrm{i}}$ represents the relative sizes of fund elements at lower-level $i-1$ compared to the fund elements at upper-level $i$. The flow ${ }_{i-1} / \mathrm{flow}_{i}$ share represents the relative amount of controlled flow by fund elements at lower-level $i-1$ compared to the amount of controlled flow by the fund element at upper-level $i$. They provide information on the structural relation between the functional parts (e.g., the size of production step-level $i-1$-with respect to the whole food chain-level $i-$, in terms of land uses, human activity or flow of electricity or $\mathrm{CO}_{2}$ emissions). The notation $i$ and $i-1$ refer to different levels of the analyzed system. For instance, if the level $i$ refer to the whole paid work sector, the level $i-1$ refer to the lower-level sectors making up the paid work sector; i.e., the agriculture, industrial and service sectors. In our case, if the upper-level refers to the whole food supply chains, the level $i-1$ would refer to lower-level compartments farm, processing, distribution, retail.

When the ratios are constructed with funds and flow categories referring to the same level, a flow $i /$ fund $_{i}$ ratio can be used to represent the speed and intensity of the system's metabolic processes: i.e., the speed at which flows are consumed or produced per unit of fund category at level $i$ (e.g., flow of fossil fuels consumed per square meter in the production phase, measured in $\mathrm{kW} \cdot \mathrm{h} / \mathrm{m}^{2}$. year, flow of added value per hour of human activity in the retail phase, measured in $€ / h)$. Intensive indicators are thus useful for characterizing the performance of a system. 


\subsection{Case Study}

As mentioned previously, the work reported here was part of the Glamur project, which evaluated and compared several food supply chains from economic, social, environmental, health and ethical perspectives. Food supply chains were classified as local or global according to the following criteria: (1) the physical/geographical distance (e.g., kilometers traveled by the product); (2) the governance and organization of the supply chains (e.g., institutions or number of intermediaries); (3) the kind of resources and technologies employed in the production process (e.g., use of traditional or hybrid seeds, technology); and (4) the role of the territory in defining the identity of the product (e.g., Protected Designation of Origin-PDO).

In the case of Spain, three specific organic tomato supply chains have been analyzed: a local, mixed, and global organic tomato supply chain. The Local supply chain consists of a network of small-size (approximately 1 hectare) agro-ecological farmers who produce a diverse range of seasonal vegetables (up to 20 products) that are sold directly to individuals or consumer groups (e.g., vegetable basket scheme). Most of the seeds are produced within the farm or obtained from an organic seed bank. Production tasks are performed mostly manually or using small machinery. Locally obtained manure is used as fertilizer. After production and harvesting, tomatoes are processed on-farm; this includes cleaning the product and preparing vegetable boxes and/or bulk products. Transport to the distribution points, where the product is delivered to consumers, is carried out by one or two members of the farm, one day a week.

The Mixed supply chain starts in a medium-size semi-diversified farm (i.e., 3 hectares and 6-7 crops), in Catalonia. The production of tomatoes is carried out outdoors, according to organic principles and using hybrid seeds, and some paid labor is hired during the summer. Tomatoes are sold through an organic wholesale cooperative in Barcelona, of which the farmer is a partner. The wholesale cooperative sells tomatoes (among other fruits and vegetables) to organic shops specializing in fruits and vegetables. Small grocery stores specializing in organic products are considered the final stage of this chain.

In the Global supply chain, tomatoes are grown in greenhouses that are normally 3 hectares in size in Almeria (south of Spain), over substrate and using an automated dripping system to deliver nutrients to the plants. Organic monoculture production principles are followed according to certification schemes, using inputs purchased on the market. Seeds are commercial hybrids. Processing takes place on-farm and consists of cleaning and packaging the tomatoes, which are then transported $800 \mathrm{~km}$ to the aforementioned organic wholesale cooperative in Barcelona. Approximately $20 \%$ of production is sold to the organic wholesaler in Barcelona. The rest is sold to other intermediaries and at private auctions, usually at lower prices than to the wholesaler in Barcelona ( $€ 0.5 / \mathrm{kg}$ on average, versus $€ 1.6 / \mathrm{kg}$ to the organic wholesaler cooperative).It should be noted that transport from Almeria to Barcelona is paid by the producer. The wholesale cooperative sells tomatoes to organic shops specializing in fruits and vegetables, which have been considered the final retail stage of this chain.

The details of the case study (i.e., the description of the organic tomato supply chain and the evaluation of their performance) are presented in [59].

\section{Results}

In this section, the main results are presented. First, the identified narratives on food supply chains in Catalonia and Spain are presented. Secondly, the attributes used to represent food supply chains from each narrative are identified. Finally, the MuSIASEM approach is applied to three organic tomato supply chains using multidimensional indicators derived from the attributes.

\subsection{Identification of Narratives}

The textual analysis performed with Atlas.ti produced five narratives: the Commodity, the Livelihoods, the Environmental, the Quality of food and the Access to food. The Commodity, the Livelihoods, 
and the Environmental predefined narratives were kept as such and described in more detail using the information contained in the reviewed documents. In contrast, within the Food security predefined narrative, two different narratives can be identified: one related to the Quality of food and the other related to Access to food. This division seems logical in the Spanish context, where the term "seguridad alimentaria" does not differentiate between the concepts of food security and food safety [60], and, in industrialized contexts these concepts have various levels of importance and are considered differently than in developing countries. These narratives were complemented with the results obtained from the lexicometric analysis, which produced four narratives: the Rural development, the Quality of food, the Commodities, and the Access to food narratives.

It should be noted that since the lexicometric analysis was performed exclusively on newspaper articles, the sample does not necessarily reflect all narratives present in society (e.g., "environmental" does not appear) whereas other narratives may be overrepresented (such as the public policy view, which is the main focus of this type of literature). Furthermore, lexicometric analysis is based on statistical correlations and does not account for meaning and context, and thus the resulting definition of narratives may diverge a little from Atlas.ti.

Narratives obtained from both methods were merged to obtain the final five narratives presented in the following sections, and these narratives were used for the definition of attributes and indicators for the quantitative analysis of the performance of food supply chains (Figure 2).

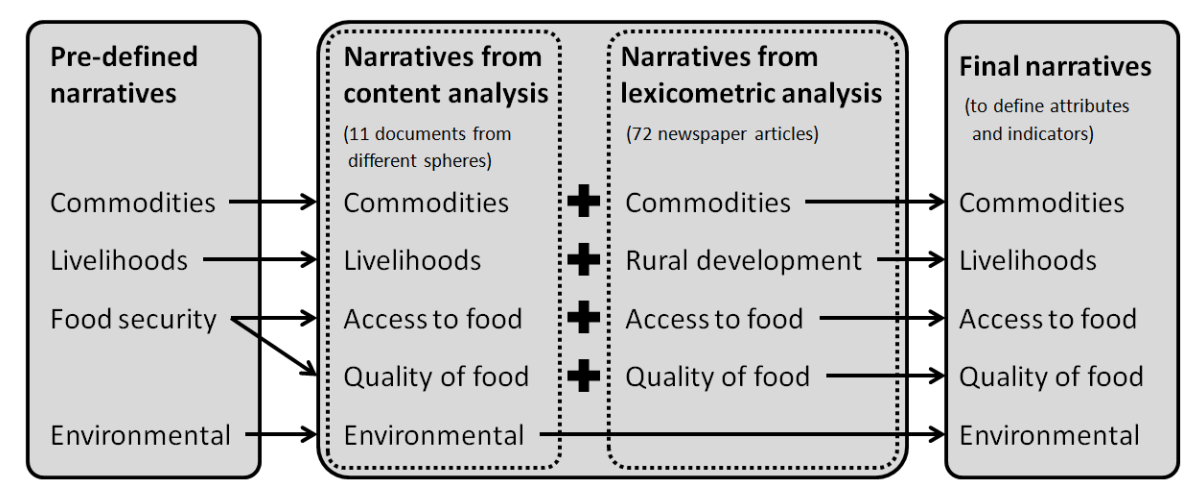

Figure 2. Process of defining the narratives used for the analysis of the performance of food supply chains.

\subsubsection{Commodity Narrative}

The Commodity narrative is characterized by the use of economic variables that act as indicators of the performance of food chains, such as price, cost, profit, added value, and competitiveness. Profitability and productivity are viewed as policy priorities. Economic productivity is determined by input costs, the quality of the production processes (modern management techniques, market orientation, planning) and the level of innovation (more innovation and investments lead to greater productivity). Company size also affects productivity: Bigger or more centralized companies enjoy economies of scale, and have better access to credit and more negotiating power in relation to distribution.

Increasing taxation on important inputs, such as electricity and fossil fuels, affects the competitiveness of the agro-food sector.

The price of the final product is an important factor, and it is linked to the number of intermediaries, the number of competitors (supply), and the cost of logistics. Price is also seen as a means of ensuring customer loyalty. However, in some cases prices are replaced with diversity of supply (diversity of products in a shop)—another aspect valued by consumers.

From the viewpoint of producers, in the context of low prices, exports become very important because they increase benefits and counterbalance the decrease in domestic consumption. Moreover, the growth and development of the agro-export sector creates jobs. Commercialization strategies are becoming more and more important, and certification can increase the value added to products. 


\subsubsection{Access to Food Narrative}

This narrative focuses mainly on the food access component of food security, i.e., having sufficient resources to obtain appropriate foods for a nutritious diet, and also on the food availability component of food security, i.e., having sufficient quantities of food available on a consistent basis, mostly considering food exchange and storage.

According to this narrative, food has become the subject of financial speculation rather than being a basic good. The volatility of food prices and increasing financial speculation associated with food commodities decreases food security by leading to a lack of, or decrease in, available and affordable food. Poor people are most affected worldwide.

This narrative highlights the difficulties which people face in accessing food during times of crisis; food consumption has decreased since the onset of the crisis in Spain and charity organizations have increased their support of poor families. These families tend to reduce food waste and increase consumption from food banks. Poor families can barely provide enough healthy food for their children. These trends are taken as the basis to call for an improvement in the quality and quantity of food delivered to people in need.

Maintaining low prices would make it easier for poor people to access food. Therefore, setting low VAT for food is viewed as an adequate policy that would help people access food.

Global food chains are seen as more risky and decrease food security. In a context of economic crisis, the volatility of food prices and financial speculation both affect people and put them in a fragile situation of low access to food in terms of both quantity and quality.

\subsubsection{Quality of Food Narrative}

This narrative focuses on the food use component of food security, which is mainly centered on food quality and safety concerns, including the information provided to consumers through labeling schemes. There is an increasing demand for quality products, and companies undergo periodic voluntary international and national quality examinations to meet these requirements. The use of quality standards, labeling, and certification schemes guarantee the quality of the production process, management, and services. They also ensure food safety (in production and distribution), lower environmental impact, and add value to the products. It is important to note that certification is mentioned as the main policy instrument in ensuring high health standards and socially responsible practices on behalf of the producer. It facilitates and promotes traceability, food safety (health), and animal welfare. Certification should be carried out by independent actors, and the quality criteria should be established with the participation of the administrations, consumers, and producers. Denomination of origin schemes provide more information to consumers, and increase the value added and the differentiation of food products. Another concern is diet, where the abandonment of the Mediterranean diet is seen as the cause of obesity and a more vegetarian diet is advocated as healthier. Consumer access to information is an important issue mentioned in this narrative. More information and transparency are advocated in order to ensure that consumers are aware of what they buy; health, ethical, and social considerations are also taken into account. Direct sales can play an important role in this regard, making fresh products, with higher organoleptic properties, available.

Convenience (i.e., foods that are easy to cook) and nutritional value are also emphasized. These characteristics, together with traditional and environmentally friendly products, are important to transmit to consumers.

This narrative is predominant in the public sphere, and focuses on the local level (mostly individual consumers).

\subsubsection{Livelihood Narrative}

The main issues raised are the exodus of the population from rural areas, prospects for rural development, and the quality of life of farmers (linked to short food chains). This narrative has a slightly more holistic point of view, as it encompasses both productive and non-productive activities, the working and non-working population, and demographic concerns. 
The Mediterranean diet is seen as a heritage that should be preserved and promoted. Moreover, peri-urban agriculture and agriculture in general should be protected against projects that negatively affect the territory.

Rural areas have suffered from an increasing exodus of workers, which threatens the future of the sector and increases the average age of the rural population, posing a challenge to rural development. Some policies try to enhance the value of rural culture, patrimony, and the environment.

Public policies should consider the context in which they are applied (i.e., the territory). There should be strong regulation of the agrarian market in order to acknowledge the social role of land and to link subsidies to quality and the creation of jobs. Producer cooperatives and associations may play an important role in making the agrarian sector economically viable and creating jobs. A system of agrarian insurance may help the agricultural sector be economically viable, for instance, by enabling farmers to deal with increasing costs and static prices. Farmers should be economically viable in order to ensure food supply, and policies should aim to avoid price fluctuations and dependence on fossil fuels. The latter is linked to an industrial mode of production and the use of genetically modified organisms.

The food chain (and the food system) should be understood holistically; their performance is mutually dependent on the surrounding environment, which must be preserved in good condition, avoiding soil erosion, water pollution, and biodiversity loss. This narrative also promotes the participation of a wide range of actors in deciding about the food chains (i.e., food sovereignty).

The narrative implies a more democratic food system, where competitiveness and growth can be fostered by balancing power relations within the food chain, which would also improve the distribution of profits. Associations and cooperatives can play an important role in bestowing more bargaining power on small actors of the food chain. Relations of cooperation and trust are reinforced through direct contact between producers and consumers.

Also, the integration of actors though the food chain would foster efficiency and transparency (e.g., labeling and traceability).

Commercial relations between producers and big distributors can be improved by means of, for instance, eliminating regulatory barriers to small retail distribution, monitoring unbalanced commercial relations, writing down contractual conditions of exchange, and setting up a round table of producers and distributors to deal with conflicting situations (i.e., develop chain regulations). The narrative is used on different scales of analysis, including the local scale both from the point of view of producers and consumers, the contribution of the agricultural sector to GDP, and its competitiveness in the international market. It is the most widely used narrative across spheres, owing to the ambiguity of the variables used (price can be viewed both as a reflection of added value and as an unfair mechanism) and to its adaptability to multiple scales. It is the only narrative that considers the entire food chain: production, transformation, distribution, and consumption.

\subsubsection{Environmental Narrative}

This narrative emphasizes the environmental impact of agricultural practices. It focuses on production and transport. An important issue raised here is the high energy consumption of the agricultural sector in terms of inputs and techniques, and the consequent environmental impact of pollution and dependence on fossil fuel imports. The narrative mostly deals with the production stage, both on the local scale (comparing organic to traditional farming) and the national scale (food security vs. energy security). The narrative appears predominantly in the public and scientific spheres.

Pollution is an important concern. Soil pollution is linked to the use of fertilizers, erosion, and the type of agriculture practiced (organic agriculture is seen as less polluting). Water pollution is linked to pig farming. Good practice standards are used as policy instruments to foster environmental protection and animal welfare.

The high use of fossil fuels by the agricultural sector for fertilizers, agrochemical treatments, and animal feed is viewed as negative because of its environmental impact and the increasing dependence 
on imports. Organic farming, reducing meat consumption, and investing in renewable energies (including agro-fuels) are suggested as means of consuming less energy and land. Embedded energy consumption is the most widely used indicator.

Also, there is a focus on other environmental impacts of agricultural practices, such as greenhouse gas emissions. Proximity is seen as a solution, in terms of reducing the ecological footprint, that supports the consumption of healthy and seasonal products, and reduces transport.

\subsection{From Narratives to Attributes}

Based on the narratives previously identified, it is now possible to identify the elements used to describe the different food chains. These elements (i.e., attributes) are listed in Table 3.

Table 3. Attributes used to describe food supply chains from different narratives.

\begin{tabular}{|c|c|c|c|c|c|}
\hline \multirow{2}{*}{ Narrative } & \multicolumn{5}{|c|}{ Dimensions } \\
\hline & Economic & Social & Environmental & Health & Ethical \\
\hline Commodity & $\begin{array}{l}\text { Access to finance } \\
\text { Competitiveness } \\
\text { Contribution to GDP } \\
\text { Cost of production } \\
\text { Economic efficiency } \\
\text { Diversity of supply } \\
\text { Innovation } \\
\text { Investment } \\
\text { Price } \\
\text { Productivity } \\
\text { Profitability } \\
\text { Quality } \\
\text { Value added }\end{array}$ & $\begin{array}{l}\text { Customer loyalty } \\
\text { Employment }\end{array}$ & Quality & Quality & - \\
\hline Access to food & $\begin{array}{l}\text { Affordability (price) } \\
\text { Food availability } \\
\text { Price stability }\end{array}$ & Food security & Wasted food & $\begin{array}{l}\text { Health Food } \\
\text { intake }\end{array}$ & - \\
\hline Quality of food & - & $\begin{array}{l}\text { Information } \\
\text { Convenience } \\
\text { Quality of food } \\
\text { (organoleptic) } \\
\text { Traceability } \\
\text { Transparency }\end{array}$ & $\begin{array}{l}\text { Environmental } \\
\text { impact }\end{array}$ & $\begin{array}{l}\text { Food safety } \\
\text { Healthy food }\end{array}$ & $\begin{array}{l}\text { Animal } \\
\text { welfare }\end{array}$ \\
\hline Livelihood & $\begin{array}{l}\text { Access to market } \\
\text { Dependence on price fluctuations } \\
\text { Distribution of profit } \\
\text { Economic viability (farmers' } \\
\text { income, production costs) } \\
\text { Price } \\
\text { Price stability }\end{array}$ & $\begin{array}{l}\text { Culture and identity } \\
\text { Employment } \\
\text { Food security } \\
\text { Food sovereignty } \\
\text { Information and } \\
\text { transparency } \\
\text { Labor availability } \\
\text { Power relations } \\
\text { Participation } \\
\text { Quality of jobs } \\
\text { Quality of life } \\
\text { Rural ageing } \\
\text { Rural development } \\
\text { Social relations } \\
\text { Traceability } \\
\text { Territory }\end{array}$ & $\begin{array}{l}\text { Biodiversity } \\
\text { Dependence on } \\
\text { fossil fuels } \\
\text { Water quality } \\
\text { Soil quality } \\
\text { Soil pollution }\end{array}$ & Healthy food & - \\
\hline Environmentalist & Dependence on external inputs & Food sovereignty & $\begin{array}{l}\text { Biodiversity } \\
\text { Energy } \\
\text { consumption } \\
\text { GHG emissions } \\
\text { Erosion } \\
\text { Soil pollution } \\
\text { Dependence on } \\
\text { fossil fuels } \\
\text { Water pollution }\end{array}$ & Healthy food & $\begin{array}{l}\text { Animal } \\
\text { welfare }\end{array}$ \\
\hline
\end{tabular}

Not all attributes can be measured in quantitative terms, i.e., not all attributes can be translated into quantitative indicators. In the representation of food chains, the first step is to choose those attributes that are suitable for quantitative assessment. This choice has been constrained mainly due to data availability. 


\subsection{From Attributes to Indicators}

For this step, we have chosen land use and human activity as the main funds to represent food chains. The following indicators have been defined.

Table 4 presents the indicators selected for four of the five narratives identified. The Quality of food narrative has not been included since the attributes used to describe and represent food supply chains require quantitative information that was not available in the case study of the organic tomato supply chains. The same applies to the representation of the health and ethical aspects that are not included in the assessment. Thus, the picture provided is simply a useful approximation, showing that different narratives result in different attributes (and thus indicators) that can be used to describe the performance of food supply chains.

Table 4. Narratives, attributes, and indicators for the Multi-Scale Integrated Assessment of Societal and Ecosystem Metabolism (MuSIASEM).

\begin{tabular}{|c|c|c|c|}
\hline Narrative & Attribute & Scale & Indicator \\
\hline \multirow{6}{*}{ Commodity } & \multirow[b]{2}{*}{ Added value } & \multirow[b]{2}{*}{ Chain } & Economic labor productivity \\
\hline & & & $\begin{array}{l}\text { Amount of added value generated per hour of } \\
\text { human activity }\end{array}$ \\
\hline & \multirow{2}{*}{ Productivity } & \multirow{2}{*}{ Farm } & Land productivity \\
\hline & & & Amount of product per $\mathrm{m}^{2}$ \\
\hline & \multirow{2}{*}{ Job creation } & \multirow{2}{*}{ Chain } & Number of jobs \\
\hline & & & Jobs per square meter \\
\hline \multirow{6}{*}{ Livelihoods } & \multirow{2}{*}{ Distribution of income } & \multirow{2}{*}{ Chain } & Distribution of income \\
\hline & & & Share of added value retained by the producer \\
\hline & \multirow{2}{*}{ Farmers' income } & \multirow{2}{*}{ Farm } & Net income \\
\hline & & & Net income per hour of familial labor \\
\hline & \multirow{2}{*}{ Job creation } & \multirow{2}{*}{ Farm } & Number of jobs \\
\hline & & & Jobs per square meter \\
\hline \multirow{4}{*}{ Access to food } & \multirow{2}{*}{ Food availability } & \multirow{2}{*}{ Chain } & Product availability \\
\hline & & & Number of months of product availability \\
\hline & \multirow{2}{*}{ Affordability } & \multirow{2}{*}{ Chain } & Price \\
\hline & & & Sales price \\
\hline \multirow{6}{*}{ Environmentalist } & \multirow{2}{*}{ Energy consumption } & \multirow[b]{2}{*}{ Farm } & Consumption of energy carriers \\
\hline & & & $\begin{array}{l}\text { Consumption of electricity fossil fuels per } \\
\text { square meter }\end{array}$ \\
\hline & \multirow{2}{*}{$\mathrm{CO}_{2}$ emissions } & \multirow{2}{*}{ Farm } & Direct $\mathrm{CO}_{2}$ emissions \\
\hline & & & Direct $\mathrm{CO}_{2}$ emissions per square meter \\
\hline & \multirow{2}{*}{ Biodiversity } & \multirow{2}{*}{ Farm } & Agro-biodiversity \\
\hline & & & Number of crops on the farm \\
\hline
\end{tabular}

\subsection{Assessment of the Tomato Supply Chains from Different Narratives}

This section demonstrates how the pre-analytical choice of different narratives leads to different assessments of food supply chains. The three organic tomato supply chains considered in Catalonia are depicted in Figure 3 using the indicators associated with the narratives defined in the previous section.

At this point, it is possible to associate the selected narratives with actual typologies of agents operating along the food supply chains. For instance, the Commodity narrative maps onto the chosen 
story-telling of business persons. The Livelihood narrative represents the story-telling of members of rural communities and/or farmers, as well as critical consumers. The narrative Food security is a typical story-telling adopted by urban consumers. Finally, many social actors-whoever is concerned with the health of the environment and the protection of nature-endorse the Environmentalist narrative. What transforms a narrative into story-telling is the existence of a story-teller having a goal, a concern, and therefore a purpose. This is what makes it possible to verify the relevance and the usefulness of a given narrative as well as the associated quantitative assessment.

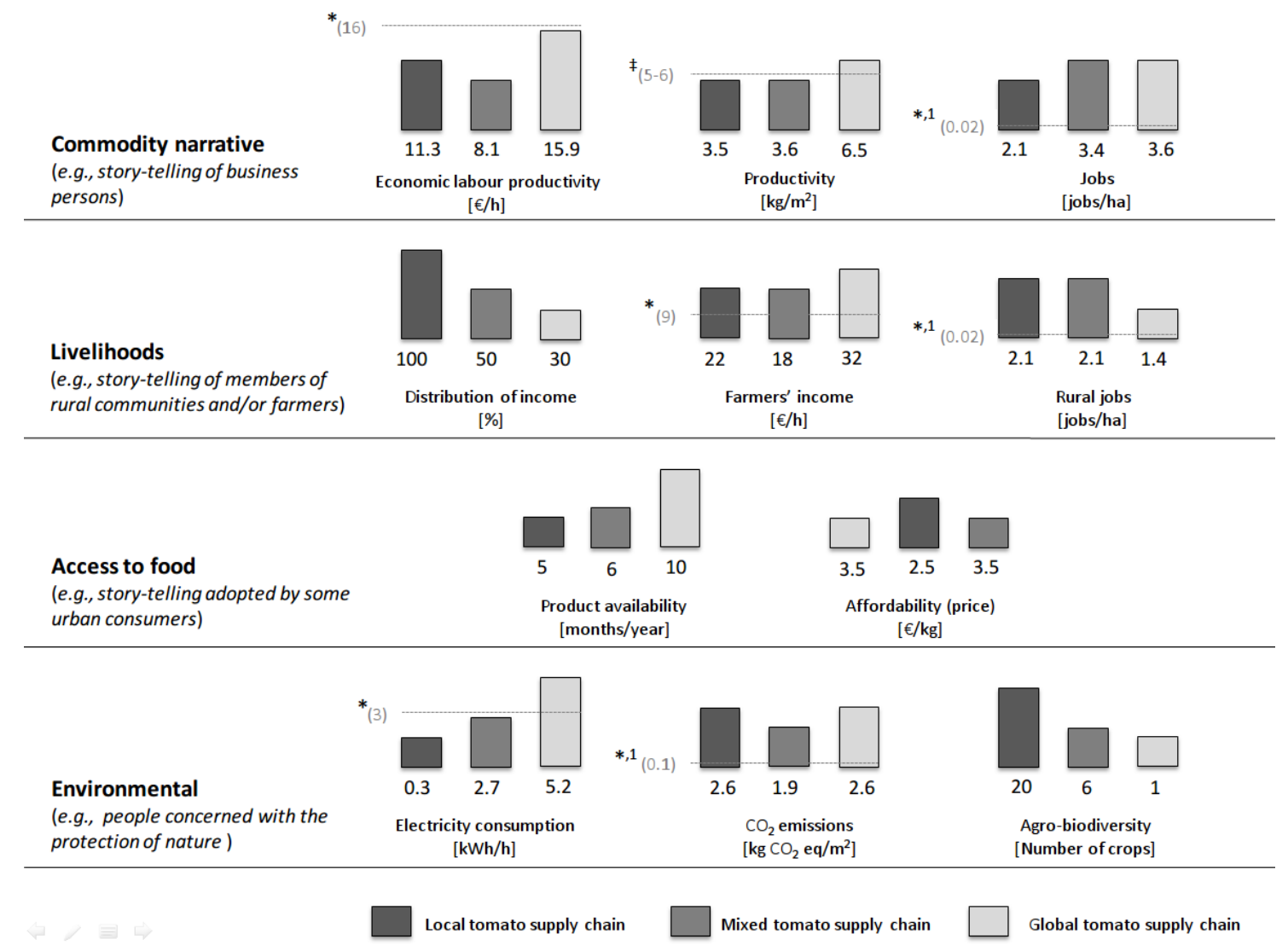

Figure 3. Characterization of the performance of the organic tomato supply chain, reflecting the existence of different story-tellers (i.e., narratives) (source: own elaboration with data from [59]). The values in brackets refer to benchmarks based on $\left(^{*}\right)$ the average of the Spanish agricultural sector; $(\ddagger)$ average of the Spanish organic tomato sector. (1) These reference values refer only to the Spanish agricultural sector. They do not consider emissions and jobs in distribution and retail activities.

It should be noted that the definition of "story-teller" is not concrete: the same individual can be a businessperson and yet care for the environment. This means that a definition of story-teller does not map 1:1 on specific typologies of social actors. In any case, organizing the indicators of performance based on typologies of story-telling and not on generic criteria of performance makes it much easier to interface the resulting quantitative information with the process of governance.

According to the indicators selected in the story-telling Commodity-useful for those actors whose survival depends on successful market transactions-the global supply chain clearly performs better. It creates higher value that is added along the chain per hour of paid work allocated to producing, distributing, and retailing tomatoes. It should be noted that the economic labor productivity of the global chain is lower than the economic labor productivity of the whole agricultural sector. The farms producing tomatoes for the global chain also present higher productivity (slightly higher than the national average of organic tomato production), which is due to cultivation in controlled environments 
in greenhouses and the drip irrigation system (i.e., the provision of nutrients through the dripping system). Also, the number of jobs created along the chain by the global and mixed supply chains is higher than in the local context. Higher employment is basically due to the contribution of activities performed in reduced spaces compared to agricultural land used for production (i.e., wholesaling and retailing). However, it should be considered that the jobs in the local and mixed chains are created for five to six months a year, whereas the jobs in the global chains last for the whole year. In the case of the local and mixed chains, for the rest of the year land is used to produce other seasonal vegetables.

According to the indicators selected in the story-telling Livelihoods-useful for those actors whose survival depends on the ability to reproduce an integrated set of socio-economic functions - the local and mixed organic tomato supply chains perform better than the global one. In this case, the creation of jobs in rural areas is prioritized, and all those working in the local supply chains are actually part of the productive project. Story-tellers of the Livelihoods narrative usually argue in favor of local food supply chains and direct selling schemes based on the fact that these supply chains favor the producer in terms of income distribution. This can be related to the issue of distribution of power between the actors along the chain. In the local chain, the producers decide the price of products, trying to balance competitiveness and the economic viability of their enterprise. In the mixed chain under study, the producers are partners of the wholesale cooperative. Here, production is planned between the partners of the cooperative in order to ensure that products will be sold through the wholesale cooperative. In both cases, however, the higher negotiation power related to the decision of what to produce and what to sell is reflected in the higher share of added value created along the chain and retained by the producer. In the global chain, prices are defined outside the farm and by actors other than the producer.

When it comes to comparing the net income per hour of familial labor allocated to producing tomatoes, the global supply chain performs better and lower sale prices are compensated for by the higher volumes produced and sold by the global farm. It should be noted that farmers operating in different chains obtain higher income per hour of familial labor than the average farmer operating in the Spanish agricultural sector.

When considering the story-telling access to food, we discover that only indicators belonging to the economic dimension were available. This confirms that this story-telling is typical of urban consumers. For them the possibility that food supply could be limited by biophysical constraints is not even considered. It is the economic accessibility of safe food products (their affordability) that matters. Also, access to food is of increasing importance in Spanish society in the context of the economic crisis. In this case, it is necessary to find a balance between the period when products are available and their price. From this perspective, the global food supply chain performs better than the mixed one since it can provide the product for the same price over a longer period of time. The local performs better in terms of price, but the product is available only for a short period of time. Considering that access to food does not depend on a single product, one could argue that with regard to the diet as a whole the local chain performs better but provides only seasonal products. Yet, health and the quality of diet were not assessed due to the focus on one product and the lack of available data.

Finally, the indicators in the environmental story-telling-useful for actors (e.g., entities such as NGOs and administrations and individuals) concerned with the preservation of ecosystems and the integrity of natural processes-clearly support the local and the mixed tomato supply chains. Global farms consume larger amounts of electricity to control the temperature inside greenhouses, which increases productivity and net income at the expense of higher biophysical costs. In fact, electricity consumption almost doubles the average electricity consumption per hour of human activity of the Spanish agricultural sector. It is worth noting that the mixed farm has similar electricity consumption to the local farm. The difference between these chains is the electricity consumption in wholesale and retail.

What seems to be striking is the high $\mathrm{CO}_{2}$ emissions caused by fossil fuel combustion in the local tomato supply chain, which is due to the use of small trucks for the distribution of the vegetable baskets. It is worth noting that these amounts are relatively small and do not challenge the sustainability of this 
activity. What is interesting here is that results indicate there is room for improvement, in operational terms, in the distribution system of local food supply chains: coordination between producers or the implementation of storage and distribution centers across the city are some actions that would make distribution tasks in direct selling schemes easier.

The local farm performs better than the mixed and global ones according to the biodiversity indicator. This is an expression of the different nature of the tomato supply chains analyzed. The local chain aims to produce and supply fresh seasonal vegetables, in a model based on relations of trust between producers and consumers. The global chain on the other hand, aims to supply tomatoes all year round, using a system detached from natural cycles. In this case, agro-biodiversity is relatively low at the level of the individual farm. However, if one considers all producers grouped in the wholesale cooperative, then the agro-biodiversity increases.

\section{Conclusions}

Food systems are complex systems that encompass a plurality of processes, from production to processing and retailing, all the way to consumption. Additionally, there is a plurality of stakeholders who affect and are affected by the events taking place in food systems. These social actors are stakeholders holding multiple stakes, as they are both producers and consumers in some instances, business persons and people concerned for the environment, and rural and urban dwellers. As a result, many non-equivalent representations of food systems can be produced, leading to different assessments of the performance of food systems. Since the definition of relevance depends on the goal of the analysis [47], a wide range of representations is needed in order to grasp the diversity of stakeholders and perspectives on food systems sustainability. This paper has used a simplified comparison of local and global food chains as a means to illustrate the complexity of assessing food systems and producing policy-relevant information in this context.

In this paper, societal metabolism analysis has been applied to the comparison of three organic tomato supply chains. This encompasses the identification of narratives and story-tellings about food supply chains and the relative attributes used to describe and represent these chains that are used by key story-tellers of the food system. Subsequently, quantitative indicators have been defined to measure how the tomato supply chains perform in terms of each attribute and from the different narratives and viewpoints. In so doing, the paper has demonstrated that the analysis of food supply chains can be semantically framed from different perspectives, which entails different problem structuring in formal terms and different performances. In fact, each chain performs differently from the perspective of each narrative: e.g., the global supply chain performs better from the commodity perspective, which is coherent with the fact that this supply chain is mostly profit-driven, and farmers compensate for low prices with large volumes of produce and supplying produce all year round. In contrast, the livelihood narrative favors the local tomato supply chain, which creates more jobs in rural areas and gives more negotiating power to farmers. The livelihood narrative shares priorities with the environmentalist narrative, in which the local supply chain also performs better. In this way, the use of attributes and indicators from different dimensions and scales has served to identify the typical trade-offs of integrated assessment. To make things more challenging, it should be noted that even when generating quantitative results using a given perspective-e.g., the economic perspective-the resulting indicators can be perceived in different ways by different actors. For example, a very high wage is good for workers but bad for investors who want to maximize profit. Paying local taxes is good for the local community but bad for outside investors. In terms of local development, it makes a difference if profit remains in the community or if it leaves.

Regarding the use of scientific information for policy making, a series of quality checks on the following aspects must be carried out:

(1) Quality check on issue definition. The narratives used to frame the problem have to be coherent with the context in which the integrated assessment is carried out. In this case, the main narratives were identified from documents dealing with food systems and food supply chains in 
Catalonia and Spain. In addition, this quality check includes the identification of relevant and plausible narratives.

(2) Quality check on integrated analysis. This includes checking whether the scales and dimensions used for the evaluation and comparison are relevant for the analysis: that is, whether the attributes and indicators used for the description and representation of the tomato supply chains really represent the narratives underlying them.

For this study, these quality checks have been performed by the research team, based on the information gathered using the reviewed documents. However, public participation at all stages of an integrated assessment is necessary. In this sense, we have to consider that different stakeholders have narratives, and these social actors would be responsible for deciding whether narratives, attributes, indicators, as well as the scale of analysis, are relevant for deliberation and policy making. Therefore, it is of key importance to consider the objectives, interests, and perspectives of a wide range of social actors when describing and representing the food system. In this way, the analysts will be able to identify relevant narratives present in society, framing the problem at hand in different ways.

Some of the limitations faced when applying this methodology include the lack of qualitative information for the evaluation and comparison. For instance, the quality of jobs, power relations, and trust are some of the attributes which mean that short food supply chains (such as the local and mixed chain of this case study) are expected to perform better.

In conclusion, the paper has demonstrated how important it is to assess narratives in order to make sense of multiple indicators and the sometimes-contradictory assessments, depending on the point of view used to perceive and represent food systems and food chains.

Acknowledgments: This work has been carried out within the framework of the EU FP7 research project "Global and Local food chain Assessment: a Multidimensional performance-based approach (GLAMUR)" (KBBE.2012.2.5-03-Grant Agreement No.: 311778). The European Union or the European Union Commission cannot be held responsible for results and opinions quoted in the text. The research of Gonzalo Gamboa is funded by the Spanish National project HAR2013-47182-C02-01 and the Catalan Research group 2014 SGR591. Marta G. Rivera-Ferre is funded by the Ramon y Cajal fellowships program.

Author Contributions: Gonzalo Gamboa has performed the lexicometric analysis and contributed to perform the textual analysis, to identify the narratives and to define the attributes and indicators to assess the food supply chains. He has participated in the case study and has led the writing of the article. Zora Kovacic has collected the sources of information, has performed the textual analysis, identified narratives, defined the attributes to assess food supply chains and contributed to write some sections of the paper. Marina Di Masso and Sara Mingorría have carried out the case study, analyzed primary data sources, defined the narratives used in the article and contributed to write some sections of the paper. Tiziano Gomiero and Marta Rivera-Ferré have collected the sources of information and contributed to write some sections of the paper. Mario Giampietro contributed to the conceptual framework and provided guidance during the various phases of the project.

Conflicts of Interest: The authors declare no conflict of interest.

\section{References}

1. Tansey, G.; Worsley, T. The Food System: A Guide; Earthscan: London, UK, 1995.

2. Lang, T.; Barling, D.; Caraher, M. Food Policy: Integrating Health, Environment and Society; Earthscan: London, UK, 2009.

3. The Food and Agriculture Organization of the United Nations-FAO. The State of Food and Agriculture; FAO: Rome, Italy, 2013; Available online: http:/ /www.fao.org/docrep/018/i3300e/i3300e.pdf (accessed on 15 January 2016).

4. Sobal, J.; Khan, L.K.; Bisogni, C. A conceptual model of the food and nutrition system. Soc. Sci. Med. 1998, 47, 853-863. [CrossRef]

5. Ericksen, P.J. Conceptualizing food systems for global environmental change research. Glob. Environ. Chang. 2008, 18, 234-245. [CrossRef]

6. Foley, J.A.; Defries, R.; Asner, G.P.; Barford, C.; Bonan, G.; Carpenter, S.R.; Chapin, F.S.; Coe, M.T.; Daily, G.C.; Gibbs, H.K.; et al. Global consequences of land use. Science 2005, 309, 570-574. [CrossRef] [PubMed] 
7. MEA (Millennium Ecosystem Assessment). Ecosystems and Human Well-Being: Synthesis; Island Press: Washington, DC, USA, 2005; Available online: http://www.millenniumassessment.org/documents/ document.356.aspx.pdf (accessed on 15 January 2016).

8. Pimentel, D.; Pimentel, M. Food, Energy, and Society, 3rd ed.; CRC Press: Boca Raton, FL, USA, 2007.

9. McIntyre, B.; Herren, H.; Wakhungu, J.; Watson, R. Agriculture at the Crossroads; Global Report; International Assessment of Agricultural Knowledge, Science and Technology for Development: Washington, DC, USA, 2009; Available online: http://www.unep.org/dewa/agassessment/reports/IAASTD/EN/Agriculture\% 20at\%20a\%20Crossroads_Global\%20Report\%20(English).pdf (accessed on 15 January 2016).

10. Nellemann, C.; MacDevette, M.; Manders, T.; Eickhout, B.; Svihus, B.; Prins, A.G.; Kaltenborn, B.P. (Eds.) The Environmental Food Crisis-The Environment's Role in Averting Future Food Crises. A UNEP Rapid Response Assessment. United Nations Environment Programme, GRID-Arendal, 2009; Available online: http://www.grida.no/files/publications/FoodCrisis_lores.pdf (accessed on 15 January 2016).

11. Gomiero, T.; Pimentel, D.; Paoletti, M.G. Is there a need for a more sustainable agriculture? Crit. Rev. Plant Sci. 2011, 30, 6-23. [CrossRef]

12. Smil, V. Should We Eat Meat? Evolution and Consequences of Modern Carnivory; Wiley-Blackwell: Oxford, UK, 2013.

13. World Food Program. 10 Hunger Facts for 2014. 2014. Available online: https://www.wfp.org/stories/10hunger-facts-2014 (accessed on 15 January 2016).

14. World Health Organization (WHO). Obesity and Overweight; Fact Sheet No. 311, Updated January 2015; World Health Organization: Gineve, Switzerland, 2015; Available online: http://www.who.int/mediacentre/ factsheets/fs311/en/ (accessed on 15 January 2016).

15. World Health Organization (WHO). Controlling the Global Obesity Epidemic; World Health Organization: Ginevra, Switzerland, 2003; Available online: http://www.who.int/nutrition/topics/obesity/en/ (accessed on 15 January 2016).

16. James, W.P.T. WHO recognition of the global obesity epidemic. Int. J. Obes. 2008, 32, S120-S126. [CrossRef] [PubMed]

17. Smil, V. Feeding the World: A Challenge for the Twenty-First Century; The MIT Press: Cambridge, MA, USA, 2001.

18. Stuart, T. Waste: Uncovering the Global Food Scandal; Penguin Books: London, UK, 2009.

19. The Food and Agriculture Organization of the United Nations, FAO. Global Food Loses and Food Waste: Extent, Causes and Prevention; FAO: Rome, Italy, 2011; Available online: http://www.fao.org/docrep/014/mb060e/ mb060e00.pdf (accessed on 4 April 2015).

20. Patel, R. Stuffed and Starved: From Farm to Fork the Hidden Battle for the World Food System; Portobello Books: London, UK, 2013.

21. Lang, T.; Heisman, M. Food Wars: The Global Battle for Mouths, Minds and Markets, 2nd ed.; Earthscan: London, UK, 2015.

22. McMichael, P. The power of food. Agric. Hum. Values 2000, 17, 21-33. [CrossRef]

23. Canavari, M., Olson, K.D., Eds.; Organic Food. Consumers' Choices and Farmers' Opportunities; Springer: New York, NY, USA, 2007.

24. Stolz, M.; Stolze, M.; Hamm, U.; Janssen, M.; Ruto, M. Consumer attitudes towards organic versus conventional food with specific quality attributes. NJAS Wagening. J. Life Sci. 2011, 58, 67-72. [CrossRef]

25. International Movement of Organic Agriculture Movements, IFOAM. Consolidated Annual Report of the IFOAM Action Group. 2014. Available online: http://www.ifoam.bio/sites/default/files/annual_report_ 2013_web.pdf (accessed on 15 January 2016).

26. Hinrichs, C.C. The practice and politics of food system localization. J. Rural Stud. 2003, 19, 33-45. [CrossRef]

27. Brown, C.; Miller, S. The impacts of local markets: A review of research on farmers markets and community supported agriculture (CSA). Am. J. Agric. Econ. 2008, 90, 1296-1302. [CrossRef]

28. Morgan, K. Local and green, global and fair: The ethical foodscape and the politics of care. Environ. Plan. A 2010, 42, 1852-1867. [CrossRef]

29. Vorley, B. Food, Inc. Corporate Concentration from Farm to Consumer; UK Food Group, International Institute for Environment and Development: London, UK, 2003.

30. Tansey, G.; Rajotte, T. The Future Control of Food; Earthscan: London, UK, 2008.

31. Barling, D.; Duncan, J. The dynamics of the contemporary governance of the world's food supply and the challenges of policy redirection. Food Secur. 2015, 7, 415-424. [CrossRef] 
32. Nestle, M. Food Politics: How the Food Industry Influences Nutrition and Health, 2nd ed.; University of California Press: Berkeley, CA, USA, 2007.

33. Committee of the Regions. Communication from the Commission to the European Parliament, the Council, the European Economic and Social Committee and the Committee of the Regions-A Better Functioning Food Supply Chain in Europe COM/2009/0591 Final, 2009. Available online: http:/ /eur-lex.europa.eu/ legal-content/EN/ALL/?uri=CELEX:52009DC0591 (accessed on 15 January 2016).

34. EC (European Commission). Communication from the Commission: Roadmap to a Resource Efficient Europe. Brussels, 2011. Available online: http://ec.europa.eu/food/safety/food_waste/library/docs/ com2011_571_en.pdf (accessed on 15 January 2016).

35. FAO-OECD. Summary Report of the Meeting. Presented at FAO/OECD Expert Meeting on Greening the Economy with Agriculture, Paris, France, 5-7 September 2011; Available online: http://www.fao.org/fileadmin/user_upload/suistainability/fao_oecd_meeting/11_12_2_FAO-OECD_ Paris_summary_report.pdf (accessed on 15 January 2016).

36. Giampietro, M. Multi-Scale Integrated Analysis of Agroecosystems; CRC Press: Boca Raton, FL, USA; London, UK, 2004.

37. Robinson, G.M.; Carson, D.A. (Eds.) Handbook on the Globalization of Agriculture; Edward Elgar: Cheltenham, UK, 2015.

38. Durham, C.A.; King, R.P.; Roheim, C.A. Consumer definitions of "Locally Grown" for fresh fruits and vegetables. J. Food Distrib. Res. 2009, 40, 56-62.

39. Hand, M.; Martinez, S. Just what does local mean? Choices 2010, 25, 13-18.

40. Rivera-Ferre, M.G.; Ortega-Cerdà, M.; Baumgärtner, J. Rethinking study and management of agricultural systems for policy design. Sustainability 2013, 5, 3858-3875. [CrossRef]

41. Funtowicz, S.; Ravetz, J. Science for the post-normal age. Futures 1993, 25, 739-755. [CrossRef]

42. Funtowicz, S.; Ravetz, J. The good, the true and the post-modern. Futures 1992, 24, 963-976. [CrossRef]

43. Rivera-Ferre, M.G. Framing of agri-food research affects the analysis of food security: The critical role of social sciences. Int. J. Soc. Agric. Food 2012, 19, 169-175.

44. Giampietro, M.; Allen, T.F.H.; Mayumi, K. The epistemological predicament associated with purposive quantitative analysis. Ecol. Complex. 2006, 3, 307-327. [CrossRef]

45. Lakoff, G. Why it matters how we frame the environment. Environ.Commun. 2010, 4, 70-81. [CrossRef]

46. Rivera Ferre, M.G.; Ortega-Cerdà, M. Recognising ignorance in decision-making. Strategies for a more sustainable agriculture. EMBO Rep. 2011, 12, 393-397. [CrossRef] [PubMed]

47. Kovacic, Z.; Giampietro, M. Beyond "beyond GDP indicators": The need for reflexivity in science for governance. Ecol. Complex. 2015, 21, 53-61. [CrossRef]

48. Rayner, S. Uncomfortable knowledge: The social construction of ignorance in science and environmental policy discourses. Econ. Soc. 2012, 41, 107-125. [CrossRef]

49. Giampietro, M.; Bukkens, S. Quality assurance of knowledge claims in governance for sustainability: Transcending the duality of passion vs. reason. Int. J. Sustain. Dev. 2015, 18, 282-309. [CrossRef]

50. Garmendia, E.; Gamboa, G. Weighting social preferences in participatory multi-criteria evaluations: A case study on sustainable natural resource management. Ecol. Econ. 2012, 84, 110-120. [CrossRef]

51. Kovacic, Z.; Giampietro, M. Empty promises or promising futures? The case of smart grids. Energy 2015, 93, 67-74. [CrossRef]

52. Magrini, T. Ballad and Gender: Reconsidering Narrative Singing in Northern Italy. Ethnomusicology Online. 1995. Available online: http://www.umbc.edu/eol/magrini/magrini.html (accessed on 15 January 2016).

53. Allen, T.F.H.; Giampietro, M. Narratives and transdisciplines for a post-industrial world. Syst. Res. Behav. Sci. 2006, 23, 1-21. [CrossRef]

54. Brunori, G.; Malandrin, V.; Rossi, A. Trade-off or convergence? The role of food security in the evolution of food discourse in Italy. J. Rural Stud. 2013, 29, 19-29. [CrossRef]

55. Köbrich, C.; Rehman, T.; Khan, M. Typification of farming systems for constructing representative farm models: Two illustrations of the application of multi-variate analyses in Chile and Pakistan. Agric. Syst. 2003, 76, 141-157. [CrossRef]

56. Bouyssou, D. Building criteria: A prerequisite for MCDA. In Readings in Multiple Criteria Decision Aid; Bana e Costa, C.A., Ed.; Springer: Berlin/Heidelberg, Germany; New York, NY, USA, 1990. 
57. Georgescu-Roegen, N. The Entropy Law and the Economic Process; Harvard University Press: Cambridge, MA, USA, 1971.

58. Georgescu-Roegen, N. (Ed.) The economics of production. In Energy and Economic Myths. Institutional and Analytical Economic Essays; Pergamon Press Inc.: Oxford, UK, 1976.

59. Gamboa, G.; di Masso, M.; Mingorria, S. Local vs. Global food supply chains. Is it possible the comparison? Manuscript in preparation. 2016.

60. Rivera-Ferre, M.G.; Soler-Montiel, M. El enfoque de la soberanía alimentaria: Más allá de la seguridad alimentaria. In Proceedings of the X Spanish Congress of Sociology, Pamplona, Navarra, Spain, 1-3 June 2010; p. 14.

(C) 2016 by the authors; licensee MDPI, Basel, Switzerland. This article is an open access article distributed under the terms and conditions of the Creative Commons Attribution (CC-BY) license (http://creativecommons.org/licenses/by/4.0/). 